\title{
Self Awareness of Adolescent Girl Students on Their Educations in Banjar Regency Indonesia
}

\author{
Dwi Nur Rachmah, Muhammad Aditya Ais Purnama \\ Psychology Study Program, Medical Faculty \\ Universitas Lambung Mangkurat \\ Banjarmasin, Indonesia \\ dwi_nurrachmah@yahoo.co.id
}

\begin{abstract}
Every year, adolescent girl students who dropped out of school in Indonesia, especially in Banjar regency, increase. The reasons for dropping out vary; some prefer to move to Islamic boarding schools, some are married, even the most severe is due to tired of the assigned task. The purpose of this research is to know about self-awareness of adolescent girls to their education. This research is a qualitative study using semistructured interview technique and nonparticipant observation. Two adolescent girls involvement in this research refer to that they have the good self-awareness to they educations, but environment factor often make them in a dilemma continue education.
\end{abstract} out

Keywords—self awareness; adolescent girls; education; drop

\section{INTRODUCTION}

This School is an institution designed to provide education for students. In Indonesian constitution 2003 about national education system define education as a conscious and planned effort to create a learning and learning process so that students actively develop their potential to have religious, spiritual strength, self-control, personality, intelligence, noble character, and skills needed by themselves, society, nation, and state (RI constitution number 20 years of 2003).

Banjar Regency until 2017 has known that student enrollment rates in Banjar Regency according to education levels continue to decline seen from the NER (Net Enrollment Rate), namely elementary school as much as 98.37 , junior high school as much as 67.28, and high school as much as 36.53 [1]. Apart from being married and helping parents work, the factors that influence are the number of students who continue their education to Islamic boarding schools. One of the causes of the NER target is still not achieved because there are many elementary school students who do not continue to junior high school, Elementary students in these villages, continue their education to Islamic boarding schools or Islamic Elementary Schools so that they are not recorded [2].

Although the previous opinion stated that why the NER number decreased because elementary school students who were considered dropping out of school were not recorded, the results of the preliminary study revealed that each year students who drop out of school are increasing, mostly in the 8th grade. The reasons for their dropping out of school vary, there are those who prefer to move to Islamic boarding schools, some are married, some drop out of school by not continuing to the next level, even the most severe are lazy because they are tired of the many tasks given in class. Various ways have been done by the school to persuade students who intend to drop out of school such as calling the parents to come to school, but there are those who are willing to come and some who do not come for busy reasons. Students who are called and given direction by the school have returned to their enthusiasm to go to school, but some have finally stopped so that this problem becomes a challenge for the school to find out why many students drop out of school in their schools.

Although the school contributes to the teaching and learning process, what needs to be observed is that students must learn and develop themselves, then to achieve this there must be cooperation between students and teachers so that the learning objectives can be achieved, and the results are satisfactory, thus in education not only teachers who have an important role in the learning process in school but the selfawareness of students who are in the learning process is also very necessary to achieve good learning outcomes. This is in line with Reasoner's opinion [3] which states that students who have high self-awareness can learn quickly, memories are more durable, respond to various challenges positively, able to accept other people, and have a great sense of responsibility for their actions. Learning outcomes, in general, can be improved by increasing awareness of student self-esteem.

Self-awareness is the condition of a person can be aware of emotions that are plaguing his mind due to the problems faced for the next he can master [4]. The lack of self-awareness of students is one of the factors why many students drop out of school at that school.

Based on the explanation, the researcher was interested in knowing more about the self-awareness of adolescent girls attending school in Junior High School at Banjar regency through qualitative research methods to get deeper results.

\section{METHOD}

First, This study uses a qualitative method with a single instrument case study approach, namely a study conducted by using a case to describe an issue or concern. Researchers pay attention to and examine an issue that is of interest in this case, namely the phenomenon of self-awareness of adolescent girls 
in East Martapura 1 Junior High School that many students have a tendency to drop out of school and use a case as a means (instrument) to describe it in detail [5].

The data was collected by using interview and observation. The type of interview used is semi-structured interviews to find problems more openly, where the parties invited to interview are asked for opinions, and ideas [6]. This interview was conducted directly on both subjects and one significant other, namely the teacher of the two subjects. While the type of observation used is non-participant observation, where researchers are not involved and only as independent observers [6], this observation was carried out when the two subjects were participating in classroom learning activities, where researchers only observed and recorded what was seen. Data analysis in this study uses thematic analysis, which focuses on detailed analysis of aspects of self-awareness of the data that is most relevant to the research question or provides a rich description of the overall data.

Credibility test in this study was carried out by triangulation, member checking, and increasing perseverance. The triangulation used is technique triangulation and source. Triangulation technique is done by combining in-depth interviews and observations about the subject, while source triangulation is done by interviewing the same material at different sources, namely on the subject and the significant others. Member checking is used after data collection is complete to obtain agreement on the results of the data. In addition, researchers also increase perseverance by making more careful observations of the results in the field with the theory used and continuously exposed.

\section{RESULT AND DISCUSSION}

The results of this study were obtained from three data sources, namely two subjects and one significant other by performing two data collection techniques namely interviews and observations made on the first subject (SA) and the second subject (FT), the outstanding students in East Martapura 1 Junior High School aged 13 years. This study also obtained data from interviews to the significant others subject namely the teacher of both subjects aged 39 years. The description of the results and discussion of this study focuses on how self-awareness as students in adolescent girls in East Martapura I Middle School is viewed from aspects of selfawareness according to [4].

\section{A. Emotional Self Awareness Aspects}

This dimension refers to the introduction of how emotions affect performance and the ability of individuals to use values in decision making. For example, if an individual is feeling happy so she can do homework faster than usual. For SA it was found that she knew what she felt and why it happened. She said that when she was in school there were many friends who made her happy, and she would be angry if disturbed or bullied by her friend. When angry because of being disturbed the subject can report to the teacher or say rudely to the person who is bothering her. Subject SA also recognizes how feelings affect her performance where when she is angry or sad, she does not focus on learning. She admitted that by going to junior high school, she could boast of her parents and want to succeed. To achieve it the subject said that does not give up and if there are problems then face it.

As for FT from the interview results, it was also found that she knew the emotions or moods she felt and why they could happen, where the subject can explain what makes her happy, angry and sad. The subject also realizes that feeling influences it both in terms of behavior, thoughts, and words, such as when a subject is happy then things that are actually not funny can make her laugh. Then the subject understands that emotions affect her performance where if she is angry then the focus in learning will be disrupted. She hopes that by becoming a student in this school makes his mother proud of her and if the grade is good, she can continue her education to high school.

\section{B. Aspects of Accurate Self-Assessment}

This dimension refers to the honesty of feelings from selfstrength and limits to a clear vision where we need to increase our ability to learn from experience. For example, if an individual gets a bad score during a test, then she is determined to get a high score by increasing her portion of learning. For SA, it is known that according to her, her weakness as a student is her lack of understanding in mathematics while for her strengths is in athletic. The subject also admitted that she had never done homework, then she was determined not to repeat the act by continuing to do homework, she had been advised by the teacher because of this. Then the subject sees herself as an angry person and sometimes can be patient, and she thinks her friend sees herself as a good person.

As for FT, it is known from the results of interviews that according to her, her weaknesses that her family has poor economic conditions, while her advantages are smart so that she can get the first rank in her class. Besides being reprimanded, she was also advised by her teacher and parents. The subject sees herself as a mediocre, less capable person, but does not mean she is not grateful about the situation but she accepts the situation and her friends see her as a good, polite, smart, and mature person.

\section{Self Confidence Aspect}

This dimension refers to the courage that comes from certainty about our abilities regarding values and goals. For example, if the individual comes to the front of the class to answer the question because they are sure they can do it. The experience of self-confidence in SA was illustrated when one time she had been called by a teacher to work on a problem in front of the class, at that time SA felt she could do the assignments given by her teacher and answer them fluently. However, sometimes she also said haltingly. She feels confident enough when asked to come to the front of the class, but she will only come to the front of the class and answer the teacher's questions if asked. SA also mentioned that if she could not answer the question, the subject would dare to tell 
her teacher that she could not. As for FT, from the results of the interview, it was found that FT subjects often come to the front of the class to answer questions or do assignments given by the teacher. When she comes to the front of the class, she feels nervous, but if she feels she can answer it, then she is not nervous and able to be calm. The subject also said that if someone else said something negative to her intentionally, she would be angry at the person and could report to the teacher for the actions of her friends who like to disturb her.

\section{Environmental Factor}

Both subjects are SA and FT have the desire to continue their education at this time and continue their education to a higher level. However, there are often various factors from the environment that make them often feel the dilemma of choosing to continue school or stop continuing their education. factors from the environment are factors of support from the family. SA's parents, namely her father, wanted their children to stop going to school and help them trade more in the market whereas FT parents want their children to move to religious schools or Islamic boarding schools instead of continuing to attend public schools.

\section{E. Discussion}

This study aims to see the picture as a whole based on the perspective of people who experience it directly about the adolescent girl self-awareness of their education. The results showed that there was self-awareness in adolescent girl attending the East Martapura 1 Junior High School in the form of Emotional Self Awareness, Accurate Self-Assessment, and self-confidence. The three forms of self-awareness found in this study are in line with the statement from [4] which mentions aspects of self-awareness about someone's recognition of emotions that affect their performance, someone's honesty about the strength they have and the desire to improve their abilities and self-confidence of her ability.

Ref [4] states that self-awareness is the ability of individuals to recognize and understand their feelings and then use them to guide decision making have realistic benchmarks for their abilities and strong self-confidence. A person whose self-awareness is good then he is able to recognize and choose feelings, understand what is being felt and why it is felt and know the cause of that feeling. This statement is in line with the findings in this study which show that the two subjects of the study were able to understand their feelings and make decisions in learning by sorting out positive and supportive feelings for the learning process such as the cheerful and happy state felt

The results of this study also note that the two subjects in this study in addition to having self-awareness in their education were also able to conduct self-regulation, especially in their learning so that they gained good academic grades and achievements. Both subjects are outstanding students; they always get the top five in their class. The results of this study are in line with the findings of a study conducted by [7] on self-awareness. Self-awareness can help individuals succeed in managing themselves. In addition, the results of this study are supported by research by [8] which states that self-awareness allows individuals to control themselves and develop positive attitudes so students can manage themselves and develop their professional attitudes. According to [9] without self-awareness individuals cannot develop a flexible and positive attitude. on the contrary, without self-management, individuals are less able to manage self-awareness properly in all situations.

Environmental factors found in this study, namely factors from the family and the economic conditions of the subject of the study made them feel the difficulties and dilemmas to continue their education in public schools. This is due to the attitude of the subject's parents (father) who asked the SA to stop going to school and focus more on helping her father trade on the market. Economic factors that were less supportive were also felt by FT because it was difficult for them to do school assignments that required her to spend money to fulfill the school assignments, such as making a craft or copying of study material.

Findings regarding family and economic support factors are in line with reference[10] study; there are several factors both internal and external that can influence students in conducting independent learning such as learning environment factors and motivational factors. There are three categories of learning environment factors, namely interactions between teachers and students, facilitation processes, and learning resources. While motivational factors consist of intrinsic motives and extrinsic motives, then the opinion of reference [11] states that family economic factors determine a lot in children's learning. For example, children in families can afford to buy complete school equipment, whereas children from poor families cannot buy the equipment. With this incomplete equipment, the hearts of children are disappointed, backward, hopeless, so their motivation to learn is lacking. Thus, the statement implies that it is important for parents to have good economic conditions because it can affect the continuity of their children's education. Thus, the motivation of parents will influence the dropout rate. Parents who do not have the desire to send their children to school can cause school dropouts. Parents with the mindset that do not develop and do not prioritize education will make children have the same mindset with them.

\section{CONCLUSION}

Based on the results of the research described earlier, it can be concluded that the description of adolescents girl selfawareness towards education can be seen from emotional selfawareness from the results of this study it was found that the two subjects in junior high school were able to recognize the feelings or emotions they felt and recognize why they could occur, as well as the effect on their performance, besides that they were also able to use values in making decisions. Second, from accurate self-assessment. Both subjects were aware of their weaknesses and strengths, they were also able to learn from experience, and what they could explain themselves. Finally, self-confidence, namely the two subjects have the 
courage to present themselves in learning and make decisions as a student.

The subject already has good self-awareness and can guide them in their role as a student, but it is the support factor of the family that makes them often feel the dilemma of continuing their education as well as economic factors.

\section{REFERENCES}

[1] Tim Badan Pusat Statistik, "Kabupaten Banjar dalam Angka 2017," Badan Pusat Statistik Kabupaten Banjar, 2017.

[2] H. Widodo, "Waduh, angka putus sekolah di Kabupaten Banjar masih tinggi, begini langkah Disdik," Banjarmasin Post, 2018.

[3] D. Zuchdi, Humanisasi Pendidikan. Yogyakarta: Bumi Aksara, 2008.

[4] D. Goleman, Working with Emotional Intelligence. New York: Bantam Books, 2011.

[5] J. Creswell, Qualitative Inquiry \& Research Design: Choosing Among Five Approaches, 2nd ed. California: Sage Publication, 2007.
[6] Sugiyono, Metode Penelitian Pendidikan Pendekatan Kuantitatif, Kualitatif, dan R\&D. Bandung: Alfabeta, 2010.

[7] S. P. Rasheed, "Self-awareness as a therapeutic tool for nurse/client relationship," International Journal of Caring Sciences, vol. 8, pp. 211216, 2015.

[8] P. Tanabe, J. Porter, M. Creary, E. Kirkwood, S. Miller, E. A. Williams, and K. Hassell, "A qualitative analysis of best self-management practices: sickle cell disease," Journal of The National Medical Association, vol. 102, pp. 1033-1041, 2010.

[9] D. Markovie, "Do Trainer Emotional Intelligence?" 2014. [Online]. Available: $\quad$ https://www.salto-youth.net/downloads/toy_trainer_ download file-2077/Dotrai.

[10] M. H. Huang, Factors Influencing Self Directed Learning Readiness amongst Taiwanese nursing student. Queensland University, 2008.

[11] A. T. Nurmalinda, I. Suntoro, Y. Nurmalisa, "Pengaruh tingkat ekonomi keluarga dan motivasi orang tua menyekolahkan anak terhadap angka putus sekolah," Jurnal Kultur Demokrasi, vol. 5, no.7, 2017. 